\title{
Inclusive Growth and Its Determinants Recent Evidence from Indonesia with Provincial Data
}

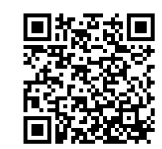

\author{
Desi Listyo Rini and Tulus Tahi Hamonangan Tambunan* \\ Center for Industry, SME and Business Competition Studies, University of Trisakti, Indonesia
}

Submission: February 02, 2021; Published: February 16, 2021

"Corresponding author: Tulus Tambunan, Center for Industry, SME and Business Competition Studies, University of Trisakti, Indonesia

\section{Abstract}

This study evaluates Indonesia's achievement in inclusive economic growth by analyzing regional data from 34 provinces for the period 2016-2018. For this purpose, the study used three indicators of achieving inclusive economic growth, namely economic growth that reduces inequality, poverty, and unemployment (or increases employment), the Poverty-Equivalent Growth Rate (PEGR) method, and the technique of multiple linear regression analysis (i.e. the fixed effect model). The results indicate that economic growth in Indonesia is not yet fully inclusive. Only a few provinces that have achieved inclusive growth. It was found that access to technology represented by the percentage of households owning a computer and access to energy represented by the percentage of households using LPG as the main fuel for cooking have positive effects on the acceleration of inclusive economic growth in Indonesia.

Keywords: Inclusive economic growth; Inclusive growth index; Poverty; Employment; Inequality

\section{Introduction}

According to Ali, Zhuang [1], Ali, Son [2], and Rauniyar and Kanbur [3], the term "inclusive economic development" has no widely accepted definition. The concept clearly encompasses inclusion and economic development, and views inclusion as a process as well as a goal. Such as Sen [4], Sachs [5], Ali, Son [2], Rauniyar and Kanbur [3], and McKinley [6] stress that inclusive economic development is economic growth coupled with equal economic opportunities. It focuses on creating economic opportunities and making them accessible to everyone in society at all levels, not just to the poor. In the same way, inclusive economic growth is one that emphasizes economic opportunities created by economic growth are freely available to all, particularly the poor $[7,8]$. Inclusive economic growth has a number of elements, which include poverty reduction, employment generation, improvement in quality of employment, agriculture development, industrial development, social sector development, reduction in regional disparities, environment protection, and equal distribution of income. Among these elements, poverty reduction, employment creation and equal distribution of income have received the most attention in empirical studies of, explicitly or implicitly, inclusive economic growth [9-15]. In Indonesia, many reforms have been carried out since the end of the 1997-98 Asian financial crisis. The government has embarked upon institutional transformation, making the country one of the region's most vibrant democracies. In the social, economic, and political fields, Indonesia has seen much progress. Wide reforms have been carried out in all areas of governance, including in the financial sector, and a new development strategy has been adopted for "inclusive" economic development $[7,8]$.

\section{Aim and research problems}

This study is part of ongoing research project on "Inclusive Development in Indonesia". The aim of this study is to evaluate Indonesia's achievement in inclusive economic growth by analyzing regional data from 34 provinces. The definition of inclusive economic growth used in this study is an economic growth that reduces poverty, income distribution inequality and unemployment.

This research focuses on the following three questions:

i. is Indonesia successful in achieving inclusive economic growth?

ii. Are there differences in achieving inclusive economic growth between provinces?

iii. What factors that most determine the achievement of inclusive economic growth in 34 provinces? 


\section{Determinant factors}

Until now there has not been so much research on inclusive growth at the provincial level in Indonesia. From very few empirical studies that the authors managed to find, there is only one study, namely from Sholihah (2014) who conducted an empirical research in 34 provinces for the 2008-2012 period. The result revealed that in 2008 only a few provinces showed inclusive growth, whereas during the 2009-2012 period none of the provinces experienced an inclusive growth. While other studies only examined one or a few provinces. Table 1 shows previous studies in Indonesia. Poverty and inequality are two most important indicators in measuring the inclusiveness of an economic growth [16-24]. So, automatically the factors that directly influence poverty and inequality become important variables in analyzing inclusive economic growth. These factors are (i) access to education and healthcare [25-38]; (ii) access to capital [39-42]; (iii) employment and business opportunities (iv) access to technology [43-50]; (vi) access to raw materials [51] (vii) access to physical infrastructure as well as non-physical infrastructure or economic infrastructure such as information and communication technology [38,52]; (viii) gender equity [52-55]; and (ix) access to energy [32]. Access to all sources of poverty reduction accelerates the achievement of inclusive economic growth.

Table 1: Previous Empirical Studies in Indonesia.

\begin{tabular}{|c|c|c|c|c|}
\hline No & Name, Year and Title & Research Variables & Model used & Conclusion \\
\hline 1 & $\begin{array}{l}\text { Sholihah, } 2014 \\
\text { Inclusive Growth: } \\
\text { Factors Affecting and } \\
\text { Its Impact on income } \\
\text { growth of Middle } \\
\text { Class in Indonesia }\end{array}$ & $\begin{array}{c}\text { Per capita income } \\
\text { Government investment in physical capital } \\
\text { School participation rate } \\
\text { Physical capital } \\
\text { Inequality } \\
\text { Agricultural sector contribution } \\
\text { Inflation } \\
\text { Population } \\
\text { Economic growth } \\
\text { Unemployment }\end{array}$ & $\begin{array}{l}\text { Panel \& Pov- } \\
\text { erty-Equiva- } \\
\text { lent Growth } \\
\text { Rate (PEGR) }\end{array}$ & $\begin{array}{l}\text { The study was conducted in } 34 \text { provinces in Indone- } \\
\text { sia in 2008-2012. it concludes that economic growth } \\
\text { in Indonesia in 2008-2012 was not inclusive. In } 2008 . \\
\text { only the Special Region of Yogyakarta (DIY) and } \\
\text { the province of West Papua experienced inclusive } \\
\text { growth. In 2010, NTT, NTB, West Kalimantan, Central } \\
\text { Kalimantan, East Kalimantan and South Sulawesi } \\
\text { were provinces that experienced inclusive growth. } \\
\text { In } 2009 \text { and } 2012 \text { none of the provinces experienced } \\
\text { inclusive growth. }\end{array}$ \\
\hline \multirow{6}{*}{2} & \multirow{6}{*}{$\begin{array}{l}\text { Azwar, } 2016 \text { have } \\
\text { anti-pro-poor growth } \\
\text { in Regional spending } \\
\text { Sulawesi Province and } \\
\text { the Factors Affecting it }\end{array}$} & Health & \multirow{6}{*}{$\begin{array}{l}\text { Social Mobili- } \\
\text { ty Curve }\end{array}$} & \multirow{6}{*}{$\begin{array}{l}\text { Factors affected inclusive growth in South Sulawesi } \\
\text { Province were health in reducing poverty and in- } \\
\text { equality. How Inclusive Growth in South and regional } \\
\text { expenditure factors that have positive influences. } \\
\text { Other factors such as unemployment, education, and } \\
\text { population have negative influences on inclusive } \\
\text { economic growth in South Sulawesi Province }\end{array}$} \\
\hline & & PEGR and Panel & & \\
\hline & & Economic growth & & \\
\hline & & Unemployment & & \\
\hline & & Education & & \\
\hline & & Population & & \\
\hline \multirow{7}{*}{3} & \multirow{7}{*}{$\begin{array}{l}\text { Prabandari, } 2018 \\
\text { Analysis of the } \\
\text { Inclusion of Economic } \\
\text { Growth in of East } \\
\text { Java and the Factors } \\
\text { Affecting it }\end{array}$} & Productive land & \multirow{7}{*}{$\begin{array}{l}\text { PEGR and } \\
\text { Panel }\end{array}$} & \multirow{7}{*}{$\begin{array}{l}\text { During the period } 2011-2015 \text { the inclusive growth } \\
\text { index in East Java had a declining trend. In this prov- } \\
\text { ince, three aspects of economic growth were more } \\
\text { dominant than other aspects, namely inequality, pov- } \\
\text { erty and unemployment. Management of resources } \\
\text { that can increase income per capita influenced the } \\
\text { acceleration of the realization of inclusive growth in } \\
\text { East Java. The role of the Government of East Java } \\
\text { Province through fiscal policy, in this case is the } \\
\text { education and health budget, was found effective in } \\
\text { accelerating the realization of inclusive growth }\end{array}$} \\
\hline & & Labor & & \\
\hline & & Investment & & \\
\hline & & Income per capita & & \\
\hline & & Education budget & & \\
\hline & & Health budget & & \\
\hline & & Average duration of School & & \\
\hline 4 & $\begin{array}{l}\text { Cahyadi et al., } 2018 \\
\text { Inclusive growth and } \\
\text { leading sector in Bali } \\
\text { Province }\end{array}$ & & PEGR & $\begin{array}{l}\text { In general, regions with an agricultural basis tended } \\
\text { to have pro-poor growth in reducing inequality but } \\
\text { had anti-pro-poor growth in labor absorption. Mean- } \\
\text { while, areas with high tourism potential ever, it has } \\
\text { pro-poor growth in employment. }\end{array}$ \\
\hline
\end{tabular}




\section{Theoretical framework and hypotheses}

Theoretically, there are two key channels through which economic growth affects employment and hence poverty and inequality, namely stronger output growth and increasing labor productivity in labor-intensive sectors [56,57]. In developing countries including Indonesia these sectors are agriculture, middle to low technology-based industries such as textile and garments, footwear, leather, furniture, tobacco, electronics, and food and beverages, and trade. However, from the literature review it revealed that an economic growth to be inclusive is influenced by many factors. In this study, as illustrated in Figure 1, 13 factors are included in the analysis of inclusive growth (IG), namely school participation rate (APS), number of community health centers (PKM), life expectancy (AHH), regional health insurance (JKD), credit outstanding of micro, small and medium enterprise (MSME), percentage of households that own a computer (KMP), percentage of households accessing the internet (INT), number of local traditional markets (PSR), length of national roads (PES), percentage of households that have access to proper sanitation (SNT), percentage of households that have access to clean water (AML), electricity (DLT), and percentage of households that use liquified petroleum gas as main fuel for cooking (LPG) ).

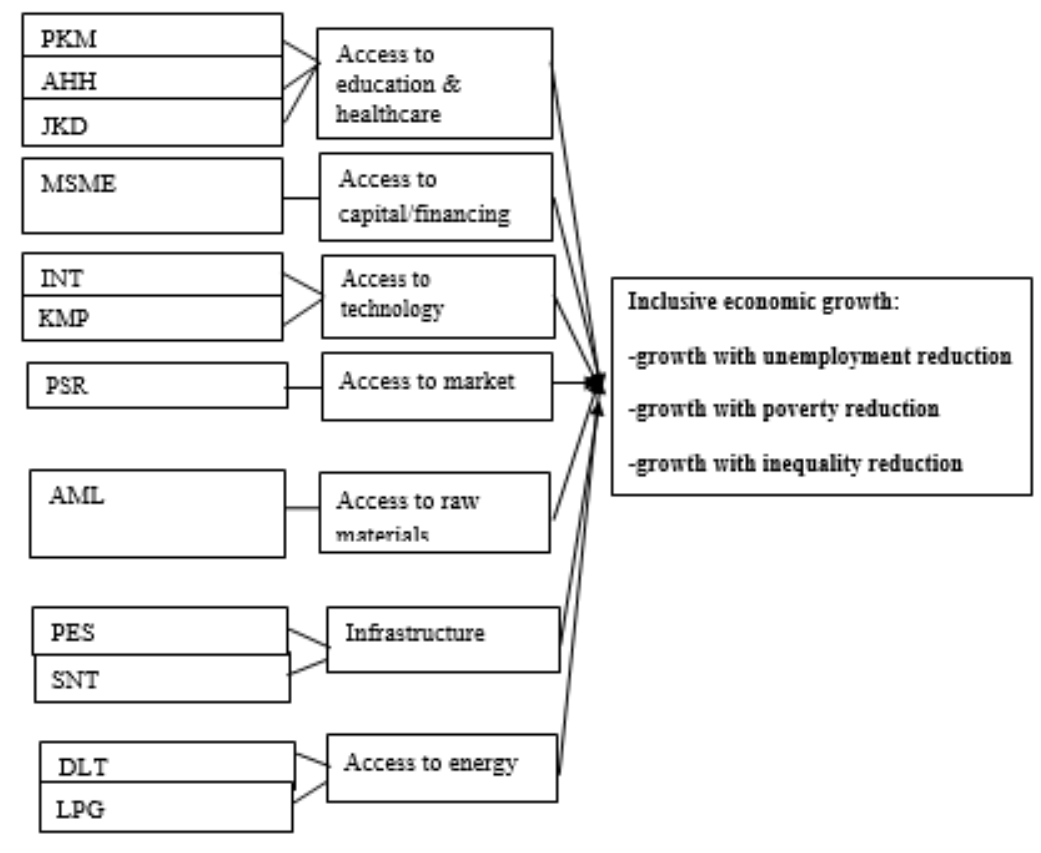

Figure 1: Theoretical framework.

Based on the theoretical framework, this research developed two hypotheses as follows:

H1: not all provinces in Indonesia achieved inclusive growth,

H2: all determinants have a positive and significant impact on inclusive growth.

\section{Research Method and Data Sources}

The model and techniques of analysis used in this study differ according to the hypothesis being tested. For H1, the analysis model used was the Poverty-Equivalent Growth Rate (PEGR) formula adopted from several previous similar studies conducted by, among others, Klasen [58], Sholihah [47], Azwar [33], and Prabandari [49]. PEGR is often used to measure the benefits of economic growth for the poor. By adopting the PEGR concept, inclusive growth can be measured by the following formula: $\zeta G_{i j}=\left(E_{i j} / E_{i}\right) x_{j}$

where:

$I G_{i j}=$ inclusive growth coefficient.

$E_{i j}=$ growth of group $i$ in relation to indicator $j$

$E_{j}=$ growth of indicator $j$.

By describing i from equation (1) as poverty (p), inequality (in) and labor (em), and j refers to indicators of economic growth (g), then by adopting the equation, inclusive growth can be measured by the following formula:

a) Inclusive growth index that reduces poverty (IGP) with the following formula:

$I G_{p}=\left(E_{p g} / E_{p}\right) \hat{G}_{g}$ 
b) Inclusive growth index that reduces inequality (IGin) with the following formula:

$$
I G_{\text {in }}=\left(E_{\text {in. }} / E_{\text {in }}\right) \widehat{G}_{g}
$$

c) Inclusive economic growth index in absorbing labor (IGem) with the following formula:

$I G_{\text {em }}=\left(E_{\text {em. }} / E_{\text {em }}\right) \hat{G}_{g}$

where:

$I G_{p}=$ inclusive growth coefficient in reducing poverty

$I G_{\text {em }}=$ inclusive growth coefficient in absorbing labor

$E_{p}=$ poverty elasticity of average income

$E_{p g}=$ poverty elasticity of economic growth

$E_{\text {em.g }}=$ employment elasticity of economic growth

$E_{\text {em }}=$ employment elasticity of average income

$E_{\text {in }}=$ inequality elasticity of average income

$E_{\text {ing }}=$ inequality elasticity of economic growth

$\widehat{G}_{g}=$ economic growth.

$I G$ index in this study is the average of the three inclusive economic growth indices combined, so that:

$$
I G=\left(I G_{i n}+I G_{p}+I G_{\text {em }}\right) / 3
$$

An economic growth can be said to be inclusive if the value of $I G \geq \widehat{\mathrm{G}}_{g}$

For H2, the technique of multiple linear regression analysis was used. In this determinant analysis, the dependent variable is inclusive growth using index values or inclusive growth coefficients and the 13 determinants as independent variables. In a multiple linear regression classic assumption tests were performed which aimed to obtain the results of a regression estimate that meets the best linear unlimited estimator requirements, which are linear, unbiased, and minimum variables, namely, normality test, heteroscedasticity test, autocorrelation test and multicollinearity test. In accordance with the variables and research objectives, an empirical linear regression regression model can be formulated according to the inclusive growth indicator approach (the results of the PEGR analysis), as shown by equation 6 , and definition of operational variables is given in Table 2 .

$$
\begin{aligned}
& I G_{i t}=\alpha_{0}+\alpha_{1} A P S_{i t}+\alpha_{2} P K M_{i t}+\alpha_{3} A H H_{i t}+\alpha_{4} J K D_{i t}+\alpha_{5} U M K M_{i t}+\alpha_{6} K M P_{i t}+\alpha_{7} I N T_{i t} \varepsilon \\
& +\alpha_{8} P S R_{i t}+\alpha_{9} P J L_{i t}+\alpha_{10} S N T_{i t}+\alpha_{11} A M L_{i t}+\alpha_{12} D L T_{i t}+\alpha_{12} L P G_{i t}+e_{1 i t}
\end{aligned}
$$

\begin{tabular}{|c|c|c|}
\hline Factors that Affect Inclusive Growth & Variable & Definitions and Variable Units \\
\hline (1) & $(2)$ & (3) \\
\hline \multirow{4}{*}{ Access to education \& healthcare } & APS & $\begin{array}{l}\text { the percentage of children in a particular school age group who are attending } \\
\text { school at an age appropriate to their age to the total number of children in the } \\
\text { school age group concerned. }\end{array}$ \\
\hline & AHH & the average number of years a person will live since that person was born \\
\hline & PKM & total availability of community health center units in unit \\
\hline & JKD & $\begin{array}{l}\text { assistance program for payment of health services provided by local govern- } \\
\text { ments in million Rupiah }\end{array}$ \\
\hline Access to capital & MSME & $\begin{array}{c}\text { principal balance of the loan ceiling agreed in the credit agreement in million } \\
\text { Rupiah }\end{array}$ \\
\hline \multirow{2}{*}{ Access to technology } & KMP & the percentage of households that have computer \\
\hline & INT & the percentage of households that has access to the internet \\
\hline Access to market & PSR & a place where people conduct trading activities in units \\
\hline Access to raw materials & AMI & the percentage of households that have access to clean water \\
\hline \multirow{2}{*}{ Infrastructure } & PES & the length of any road that is open to public vehicle traffic in kilometers $(\mathrm{km})$ \\
\hline & SNT & percentage of households that have access to proper sanitation \\
\hline \multirow{2}{*}{ Access to energy } & DLT & $\begin{array}{l}\text { electricity flow from the electricity transmission system to the consumer } \\
\text { (giga watt per hour/GWh) }\end{array}$ \\
\hline & LPG & $\begin{array}{l}\text { percentage of households that use liquified petroleum gas as main fuel for } \\
\text { cooking }\end{array}$ \\
\hline
\end{tabular}

Table 2: Definition of Operational Variables.

This study used panel data or cross section data of 34 provinces for 2016, 2017 and 2018 from two sources, namely Bappenas (2018) for PKM variable, and the Central Statistics Agency (BPS, 2015a,b; 2016; 2017; 2018a,b,c; 2019a,b,c,d,e) for the remaining independent variables. Ideally, a dynamic model over a longer time period would be more appropriate. However, for other years, not all provinces have data for all variables. 


\section{Findings}

\section{Economic growth, poverty, inequality, unemployment}

Since the end of the 1998 Asian financial crisis that forced the Indonesian economy to drop sharply with a growth rate of minus 13 per cent, Indonesia's economic growth rate has never exceeded 5.5 per cent compared to an average of 7 to 8 per cent that ever achieved before the crisis. However, looking at the development of the three main components of inclusive growth, it seems that Indonesia is on the right track towards inclusive growth. As can be seen in Figure 2, the level of inequality tends to decline; although it is not significant and still falls into the category of moderate inequality. Indeed, reducing inequality remains a serious problem in Indonesia which has not been easy to overcome. This may suggest that more government efforts are still needed to achieve inclusive growth. The number of poor people and the level of unemployment also shows a declining trend. Economic growth in a region can be said to be inclusive if its inclusive growth index
$(I G)$ is greater or equal to its economic growth $(\hat{G} g)$. The results show that in 2017 and 2018 IG is below the economic growth rate although the inclusive economic index grew much faster (39\%) than the increased economic growth rate (2\%) during that period (Figure 3). This means that Indonesia's economic growth is not inclusive yet because only a few provinces have achieved inclusive growth during that period. Of the 68 observations (34 provinces in 2017 and 2018), only 8 observations that achieved inclusive growth. Meanwhile, as shown in Table 3, economic growth, poverty, open unemployment and inequality vary by province. To some degree, these variations reflect differences in many growth factors between provinces including the availability of resources, the average level of education of the workforce, economic structure, and infrastructure development. In 2018, the highest economic growth was achieved by Papua and West Papua ranked second. Their high growth rates were influenced greatly by the wealth of their natural resources, especially mining such as copper, gold, oil and gas.

Table 3: Economic Growth, Poverty, Inequality, and Unemployment by Province in 2017 and 2018.

\begin{tabular}{|c|c|c|c|c|c|c|c|c|}
\hline \multirow{2}{*}{ Province } & \multicolumn{2}{|c|}{ Economic growth } & \multicolumn{2}{|c|}{ Poverty (\%) } & \multicolumn{2}{|c|}{ Inequality (gini ratio) } & \multicolumn{2}{|c|}{ Unemployment (\%) } \\
\hline & 2017 & 2018 & 2017 & 2018 & 2017 & 2018 & 2017 & 2018 \\
\hline Papua & 4.78 & 8.25 & 27.76 & 27.43 & 0.398 & 0.398 & 3.62 & 3.2 \\
\hline West Papua & 6.32 & 7.69 & 23.12 & 22.66 & 0.387 & 0.391 & 6.49 & 6.3 \\
\hline North Maluku & 8.3 & 7.59 & 6.44 & 6.62 & 0.33 & 0.336 & 5.33 & 4.77 \\
\hline Maluku & 5.11 & 7.39 & 18.29 & 17.85 & 0.321 & 0.326 & 9.29 & 7.27 \\
\hline West Sulawesi & 6.54 & 7.25 & 11.18 & 11.22 & 0.339 & 0.366 & 3.21 & 3.16 \\
\hline Gorontalo & 7.79 & 6.47 & 17.14 & 15.83 & 0.405 & 0.417 & 4.28 & 4.03 \\
\hline South Sulawesi & 7.74 & 6.41 & 9.48 & 8.87 & 0.429 & 0.388 & 5.61 & 5.34 \\
\hline Southeast Sulawesi & 6.08 & 6.41 & 11.97 & 11.32 & 0.404 & 0.392 & 3.3 & 3.26 \\
\hline Central Sulawesi & 9.12 & 6.23 & 14.22 & 13.69 & 0.345 & 0.317 & 3.81 & 3.43 \\
\hline North Sulawesi & 6.53 & 6.12 & 7.9 & 7.59 & 0.394 & 0.372 & 7.18 & 6.86 \\
\hline North Kalimantan & 7.04 & 6.1 & 6.96 & 6.86 & 0.313 & 0.304 & 5.54 & 5.22 \\
\hline East Kalimantan & 1.62 & 6.07 & 6.08 & 6.06 & 0.333 & 0.342 & 6.91 & 6.6 \\
\hline South Kalimanta & 4.46 & 5.98 & 4.7 & 4.65 & 0.347 & 0.34 & 4.77 & 4.5 \\
\hline Central Kalimantan & 5.28 & 5.78 & 5.26 & 5.1 & 0.327 & 0.344 & 4.23 & 4.01 \\
\hline West Kalimantan & 5.81 & 5.65 & 7.86 & 7.37 & 0.329 & 0.325 & 4.36 & 4.26 \\
\hline West Nusa Tenggara & 0.61 & 5.5 & 15.05 & 14.63 & 0.378 & 0.391 & 3.32 & 3.72 \\
\hline East Nusa Tenggara & 5.29 & 5.5 & 21.38 & 21.03 & 0.359 & 0.359 & 3.27 & 3.01 \\
\hline Bali & 4.01 & 5.48 & 4.14 & 3.91 & 0.379 & 0.364 & 1.48 & 1.37 \\
\hline Aceh & 3.55 & 5.43 & 15.92 & 15.68 & 0.329 & 0.318 & 6.57 & 6.36 \\
\hline Banten & 5.82 & 5.38 & 5.59 & 5.25 & 0.379 & 0.367 & 9.28 & 8.52 \\
\hline East Java & 5.76 & 5.37 & 11.2 & 10.85 & 0.415 & 0.371 & 4 & 3.99 \\
\hline Central Java & 5.4 & 5.32 & 12.23 & 11.19 & 0.365 & 0.357 & 4.57 & 4.51 \\
\hline D.I.Yogyakarta & 5.26 & 5.32 & 12.36 & 11.81 & 0.44 & 0.422 & 3.02 & 3.35 \\
\hline West Java & 5.45 & 5.3 & 7.83 & 7.25 & 0.393 & 0.405 & 8.22 & 8.17 \\
\hline DKI Jakarta & 5.84 & 5.28 & 3.78 & 3.55 & 0.409 & 0.39 & 7.14 & 6.24 \\
\hline
\end{tabular}


Annals of Social Sciences \& Management studies

\begin{tabular}{|c|c|c|c|c|c|c|c|c|}
\hline Kep. Riau & 2.56 & 5.14 & 6.13 & 5.83 & 0.359 & 0.339 & 7.16 & 7.12 \\
\hline Kep. Bangka Belitung & 2.91 & 5.07 & 5.3 & 4.77 & 0.276 & 0.272 & 3.78 & 3.65 \\
\hline Lampung & 5.3 & 4.77 & 13.04 & 13.01 & 0.333 & 0.326 & 4.33 & 4.06 \\
\hline Bengkulu & 4.59 & 4.76 & 15.59 & 15.41 & 0.349 & 0.355 & 3.74 & 3.51 \\
\hline South Sumatra & 5.97 & 3.7 & 13.1 & 12.82 & 0.365 & 0.341 & 4.39 & 4.23 \\
\hline Jambi & 5.2 & 1.28 & 7.9 & 7.85 & 0.334 & 0.335 & 3.87 & 3.86 \\
\hline Riau & 2.53 & 0.18 & 7.41 & 7.21 & 0.325 & 0.347 & 6.22 & 6.2 \\
\hline West Sumatra & 5.41 & -1.43 & 6.75 & 6.55 & 0.312 & 0.305 & 5.58 & 5.55 \\
\hline North Sumatra & 5.56 & -17.79 & 9.28 & 8.94 & 0.335 & 0.311 & 5.6 & 5.56 \\
\hline Indonesia & 5.22 & 5.05 & 10.12 & 9.66 & 0.391 & 0.384 & 5.5 & 5.34 \\
\hline
\end{tabular}

Sources: BPS (2015a; 2016; 2017; 2018a,b; 2019b,c,d,e)

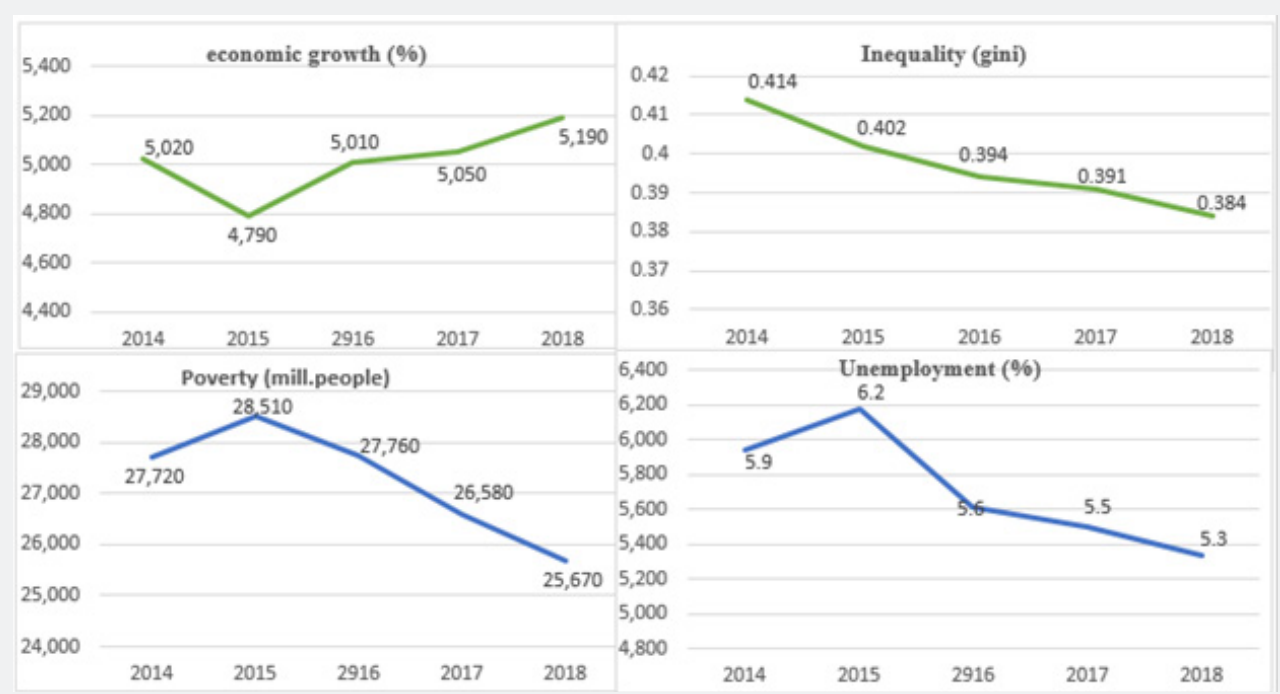

Figure 2: Economic Growth, Inequality, Poverty, and Unemployment in Indonesia during 2014-2018.

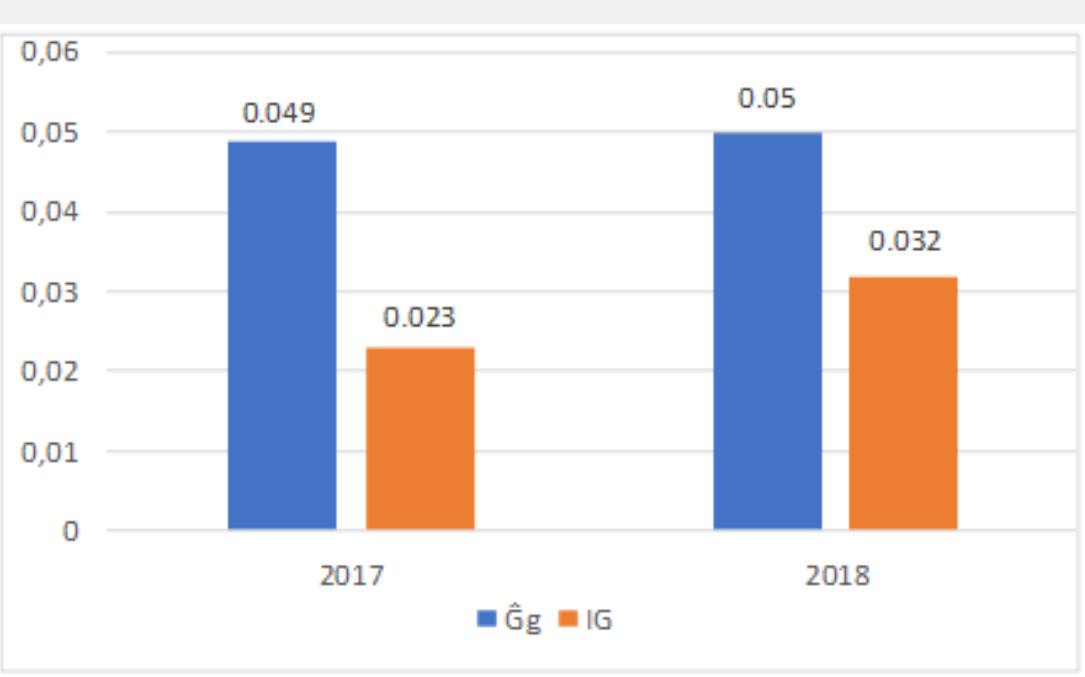

Figure 3: Average Inclusive Growth Index in Indonesia. 


\section{Annals of Social Sciences \& Management studies}

\section{Inclusive growth index}

As already explained in the metodology, in this study three coefficients of the inclusive growth index were analyzed using provincial data. First, the coefficient of economic growth that reduces poverty. Economic growth is said to be inclusive if the $I G p$ coefficient is greater or equal to the $G g$ coefficient. Second, the coefficient of economic growth that reduces inequality. Economic growth is inclusive if the $I G_{\text {in }}$ coefficient is greater or equal to the Gg coefficient. Third, the coefficient of economic growth that increases labor absorption. Economic growth is considered inclusive if the $I G_{e m}$ coefficient is greater or equal to the ${ }^{G_{g}}$ coefficient. With respect to poverty. the results show that in 2017 only four provinces had achieved inclusive growth and increased to seven provinces in 2018 (Table 4). It is obvious that most provinces in Indonesia have economic growth that is not yet inclusive in reducing poverty. Their $I G p$ coefficient is positive but smaller than their $G_{g}$ coefficient, meaning that poverty continued to decrease, but only a small portion of the poor did benefit from the growth. North Kalimantan, the newest province in Indonesia, has negative coefficients in both years. This means that economic growth was enjoyed by people who were not poor (anti poor). A negative coefficient also indicates that economic growth cannot explain its role in reducing poverty, and even tends to exacerbate poverty [58-60].

Table 4: Economic Growth and Inclusive Growth by Province, 2017-2018.

\begin{tabular}{|c|c|c|c|c|}
\hline \multirow{3}{*}{ Province } & \multicolumn{4}{|c|}{ Period } \\
\hline & \multicolumn{2}{|c|}{2017} & \multicolumn{2}{|c|}{2018} \\
\hline & IG & Gg & IG & Gg \\
\hline Aceh & 0.02 & 0.04 & 003 & 0.05 \\
\hline North Sumatra & 0.04 & 0.05 & 0.04 & 0.05 \\
\hline Riau & 0.01 & 0.03 & 0.03 & 0.02 \\
\hline Jambi & 0.01 & 0.05 & 0.04 & 0.05 \\
\hline South Sumatra & 0.01 & 0.05 & 0.03 & 0.06 \\
\hline Bengkulu & 0.01 & 0.05 & 0.04 & 0.05 \\
\hline Lampung & 0.01 & 0.05 & 0.04 & 0.05 \\
\hline Kep. Bangka Belitung & 0 & 0.04 & 0.05 & 0.04 \\
\hline Kep. Riau & 0.02 & 0.02 & 0.02 & 0.04 \\
\hline DKI Jakarta & $-0,01$ & 0.06 & 0.03 & 0.06 \\
\hline West Java & 0.04 & 0.05 & 0.04 & 0.05 \\
\hline Central Java & 0.03 & 0.05 & 0.03 & 0.05 \\
\hline DI Yogyakarta & 0.02 & 0.05 & 0.03 & 0.06 \\
\hline East Java & 0.03 & 0.05 & 0.03 & 0.05 \\
\hline Banten & 0.01 & 0.06 & 0.03 & 0.06 \\
\hline Bali & 0.01 & 0.05 & 0.03 & 0.06 \\
\hline West Nusa Tenggara & 0.01 & 0 & 0 & $-0,05$ \\
\hline East Nusa Tenggara & 0.03 & 0.05 & 0.03 & 0.05 \\
\hline West Kalimantan & 0.01 & 0.05 & 0.04 & 0.05 \\
\hline Central Kalimantan & 0.01 & 0.07 & 0.05 & 0.05 \\
\hline South Kalimantan & 0.02 & 0.05 & 0.03 & 0.05 \\
\hline East Kalimantan & 0 & 0.03 & 0.03 & 0.03 \\
\hline North Kalimantan & -1.76 & 0.07 & $-17,23$ & 0.06 \\
\hline North Sulawesi & 0 & 0.06 & 0.04 & 0.06 \\
\hline Central Sulawesi & 0 & 0.07 & 0.03 & 0.06 \\
\hline South Sulawesi & 0,01 & 0.07 & 0.04 & 0.07 \\
\hline Southeast Sulawesi & 0 & 0.07 & 0.03 & 0.06 \\
\hline Gorontalo & 0.02 & 0.07 & 0.04 & 0.06 \\
\hline West Sulawesi & 0.01 & 0.06 & 0.04 & 0.06 \\
\hline
\end{tabular}


Annals of Social Sciences \& Management studies

\begin{tabular}{|c|c|c|c|c|}
\hline Maluku & 0 & 0.06 & 0.04 & 0.06 \\
\hline North Maluku & 0.02 & 0.07 & 0.03 & 0.08 \\
\hline West Papua & 0.03 & 0.04 & 0.04 & 0.06 \\
\hline Papua & 0.04 & 0.05 & 0.03 & 0.07 \\
\hline
\end{tabular}

With respect inequality, in 2017 there were four provinces that had achieved inclusive growth, i.e. Kep province. Riau, West Nusa Tenggara, West Papua and Papua and increased in 2018 to six provinces, i.e. Riau, Jambi, Kep. Bangka Belitung, West Java, West Nusa Tenggara and East Kalimantan. Kep Riau, Papua and West Papua failed to maintain their inclusive growth in 2018. Whereas the province of West Nusa Tenggara was able to maintain its inclusive growth in reducing inequality for two years in a row. Regarding employment or unemployment, in 2017 there were five provinces that have achieved inclusive growth in increasing employment, i.e. North Sumatra, Kep. Riau, West Java, East Java and North Kalimantan, and increased in 2018 to seven provinces, i.e. North Sumatra, Riau, Kep. Bangka Belitung, Central Kalimantan, East Kalimantan, Gorontalo and Maluku. Overall, the number of provinces with inclusive growth increased between from only 2 in 2017 to 4 in 2018. North Kalimantan was the only province that experienced a drop in $I G$ from -1.76 in 2017 to -17.23 in 2018 [61-72].

This was mainly due to a significant decline of $I G p$ from -5.44 in 2017 to -51.76 years 2018 .

Next, Chow test and Hausman test were performed to determine the panel model to be used, and the results show that the probability value of Chi-Square is smaller than 0.05 . This means that a more appropriate model to be used to estimate the effect of independent variables on IG is the fixed effect model. The estimation results are as follows:

IGit $=0,083799+0,009339 A P S+0,105092 \ln P K M+(0,035748) A H H+0,001071$ JKD $+(0,076630) \ln U M K M$ $+(0,009991) K M P+0,000747 I N T+(0,005871) \ln P S R+0,147089 \ln P J L+0,000132 S N T+$

$0,001535 A M L+0,015971 D L T+0,006703 L P G(7)$

Finally, two tests were carried out, namely the individual parameter significance test (t-test) to see whether each of these independent variables individually affected IG significantly, and the simultaneous significance test (F-test) to see whether all of these independent variables together affected IG significantly (Table 5). The results of the t-test show that there are only two variables whose probability value is smaller than 0.05 , which means that each of them significantly affect the $I G$, namely the percentage of households that own computer and the percentage of households that use LPG as fuel for cooking. While the F-test results show a probability value smaller than 0.05 , which means that together all these independent variables have a significant effect on $I G$.

Table 5: Fixed Effect Estimation Results.

\begin{tabular}{|c|c|c|c|c|}
\hline Variable & Coefficient & Std Error & t-Statistic & Prob. \\
\hline $\mathrm{C}$ & 0.118414 & 3.720069 & 0.031831 & 0.9749 \\
\hline LPG & 0.006703 & 0,002569 & 2.609054 & 0.0164 \\
\hline LNDLT & 0.015971 & 0.019689 & 0.811175 & 0.4264 \\
\hline SNT & 0.000132 & 101957 & 0.067576 & 0.9468 \\
\hline AML & 0.001535 & 0.002305 & 0.665836 & 0.5128 \\
\hline LNPJL & 0.147089 & 0.204421 & 0.719541 & 0.4797 \\
\hline LNPSR & -0.00587 & 0.011634 & -0.50462 & 0.6191 \\
\hline INT & 0.000747 & 0.00088 & 0.848918 & 0.4055 \\
\hline KMP & -0.00999 & 0.004619 & -2.1632 & 0.0422 \\
\hline LNUMKM & -0.076630 & 103327 & -0.74163 & 0.4665 \\
\hline JKD & 0.001071 & 100997 & 1.074056 & 2950 \\
\hline LNPKM & 0.105092 & 0.058352 & 1.801 & 861 \\
\hline $\mathrm{AHH}$ & -0.03575 & 0.051418 & -0.69524 & 0.4945 \\
\hline APS & 0.009339 & 0.020845 & 0.447996 & 0.6587 \\
\hline \multicolumn{5}{|c|}{ Ettects Specification } \\
\hline \multicolumn{5}{|c|}{ Cross-section fixed (dummy variables) } \\
\hline R-squared & 0.870438 & Mean dependent var & & 0.027571 \\
\hline Adjusted R-squared & 0.586635 & S.D. dependent var & & 29865 \\
\hline
\end{tabular}


Annals of Social Sciences \& Management studies

\begin{tabular}{|c|c|c|c|c|}
\hline S.E. of regression & 0.019201 & Akaike info criterion & -.4 .860343 \\
\hline Sum squared resid & 0.007742 & Schwarz criterion & -3.32627 \\
\hline Log likelihood & 2122516 & Hannan-Quinn criter & -4252496 \\
\hline F-statistic & 3.067048 & Durbin-Watson stat & 3.885714 \\
\hline Prob(F-statistic) & 0.003509 & & \\
\hline
\end{tabular}

\section{Conclusion and Research Limitation}

There are two important findings from this research. First, although at the national level poverty, inequality and unemployment continued to decline, the economic growth in Indonesia is not yet fully inclusive. The average inclusive growth index in Indonesia is still below the average economic growth. Meanwhile the achievement of inclusiveness at the regional level shows different results between provinces. However, looking at the average index value of inclusive growth, at least during the 2017-2018 period, IG Indonesia shows an upward trend. In 2017 the provinces that had experienced inclusive growth were Kep Riau and West Nusa Tenggara, and in 2018 were Kep. Bangka Belitung, West Nusa Tenggara, East Kalimantan and Riau. So, it can be concluded that Indonesia is well in a good track. Second, the percentage of households that own computer that represents households' access to technology and the percentage of households that use LPG gas as the main fuel for cooking that represents their access to energy are two factors that have strong influences in accelerating the realization of inclusive growth in Indonesia. However, this research has some limitations which are the followings:

i) this study only used thirteen variables, i.e school participation rate, number of Puskesmas, life expectancy, regional health insurance, road length, number of traditional markets, number of households that own computers, users of the Internet, access to proper drinking water, access to proper sanitation, electricity distribution, and the use of LPG fuel for cooking. It is most likely that there are still many other determinants of inclusive economic growth at the provincial level but not included in this study due to data problem,

ii) the time frame used is only 2017-2018. Ideally, a dynamic model over a longer time period would be more appropriate. However, for other years, not all provinces have data for all variables,

iii) the data used is provincial data. If the study population is regencies or cities throughout Indonesia (if data are available), the results will be different.

\section{References}

1. Ali I, Zhuang J (2007) Inclusive Growth toward a Prosperous Asia: Policy Implications. ERD Working Paper Series No. 97. Manila: Asian Development Bank, Philippines.

2. Ali I, Son H (2007) Defining and Measuring Inclusive Growth: Application to the Philippines. ERD Working Paper Series No. 98. Manila: Asian Development Bank, Philippines.
3. Rauniyar G, Kanbur R (2009) Inclusive Growth and Inclusive Development: A Review and Synthesis of Asian Development Bank Literature", Occasional Paper 8, Manila: Asian Development Bank, Philippines.

4. Sen A (1999) Development as Freedom, Knopf, New York, USA.

5. Sachs I (2004) Inclusive Development Strategy in an Era of Globalization Working Paper 35. Policy Integration Department, World Commission on the Social Dimension of Globalization. Geneva: International Labour Organization, Switzerland.

6. McKinley, Terry (2010) Inclusive Growth Criteria and Indicators: An Inclusive Growth Index for Diagnosis of Country Progress", ADB Sustainable Development Working Paper Series, No. 14, Manila: Asian Development Bank, Philippines.

7. Tambunan, Tulus TH (2012) Indonesia: Building an Inclusive Development Model. In Yunling Z, Kimura F, Oum S (eds.), Moving Toward A New Development Model for East Asia: The Role of Domestic Policy and Regional Cooperation. Economic Research Institute for ASEAN and East Asia (ERIA) Research Project Report, No.10. Jakarta.

8. Tambunan, Tulus TH (2015) Financial Inclusion, Financial Education, and Financial Regulation: A Story from Indonesia, ADBI Working Paper 535, Asian Development Bank Institute, Tokyo.

9. Alesina A, Rodrik D (1994) Distributive Policies and Economic Growth. Quarterly Journal of Economics 109(2): 465-490.

10. Barro R (2000) Inequality and Growth in a Panel of Countries. Journal of Economic Growth 5(1): 5-32.

11. Bourguignon F (2003) The Growth Elasticity of Poverty Reduction; Explaining Heterogeneity across Countries and Time Periods, In Eicher T, Turnovsky S (eds.), Inequality and Growth: Theory and Policy Implications. Cambridge, Massachusetts, United States.

12. Commission on Growth and Development (2008) Growth Report Strategies for Sustained Growth and Inclusive Development, World Bank, Washington DC, United States.

13. World Bank (2008) What Are the Constraints to Inclusive Growth in Zambia? Report No. 44286-ZM, Washington DC, USA.

14. OECD OECD guidelines for multinational enterprises, Organization for Economic Cooperation and Development, Paris.

15. Prabandari, Dara Ayu, Niken (2018) Analisis Inklusitivitas Pertumbuhan Ekonomi di Jawa Timur dan Faktor-Faktor yang Mempengaruhinya, Malang: Bagian Perbit Universitas Brawijaya.

16. Anand S, Sen AK (2000) The income component of the human development index. Journal of Human Development 1(1): 83-106.

17. Bavinck M Chuenpagdee R, Jentoft S, Kooiman J (eds.), (2013) Governability of Fisheries and Aquaculture: Theory and Applications. MARE Publication Series 7, Dordrecht: Springer.

18. Rauniyar G, Kanbur R (2010) Inclusive development: Two papers on conceptualization, application, and the ADB perspective", Manila: Asian Development Bank, Philippines.

19. Sen A (2010) The place of capability in a theory of justice. In Brighouse H, Robeyns I (eds.), Measuring Justice: Primary Goods and Capabilities. Cambridge: Cambridge University Press, United Kingdom. 
20. UNDP (2010) Human Development Report 2010: The Real Wealth of Nations: Pathways to Human Development, United Nations Development Programme, New York.

21. ADB (2007) Long-Term Strategic Framework: Lessons from Implementation (2001-2006), Manila: Asian Development Bank.

22. ADB (2008) Strategy 2020: The Long-Term Strategic Framework of the Asian Development Bank, 2008-2010. Manila: Asian Development Bank, Philippines.

23. ADB (2012) Framework of Inclusive Growth Indicators 2012: Key Indicators for Asia and the Pacific: Special Supplement, $2^{\text {nd }}$ edition, Manila: Asian Development Bank, Philippines.

24. OECD (2015) Better life initiative: Measuring well-being and progress, Paris: Organization for Economic Cooperation and Development.

25. Arsyad L, Ekonomi Pembangunan (1999) Yogyakarta: Bagian Penerbitan STIE YKPN,

26. Suchrcke, Marc Martin McKee, Regina Sauto Arce, Svetla Tsolova and Jørgen Mortensen (2005) The Contributuion of Health in The Economy in The European Union. Health and Consumer Protection European Communities, Luksemburg: European Communities.

27. Suryawati, Criswardani (2007) Memahami Kemiskinan Multidimensional.

28. Habito, Cielito F (2009) Patterns of Inclusive Growth in Developing Asia: Insights from an Enhanced Growth-Poverty Elasticity Analysis, ADBi Working Paper Series No. 145, Asian Development Bank Institute, Tokyo.

29. Abosede AJ, Onakoya AB (2013) Entrepreneurship, economic development and inclusive growth. International Journal of Arts and Entrepreneurship1(3): 375-387.

30. Oxfam (2014a) Working for the Few. Political Capture and Economic Inequality, Oxfam Briefing Paper 178. Oxford Committee for Famine Relief, London.

31. Oxfam (2014b) Even it Up: Time to End Extreme Inequality, London: Oxford Committee for Famine Relief.

32. Gupta, Joyeeta, Nicky RM, Pouwb and Mirjam AF, Ros-Tonen (2015) Towards an Elaborated Theory of Inclusive Development. European Journal of Development Research 27(1): 541-559.

33. Azwar (2016) Pertumbuhan Inklusif di Provinsi Sulawesi Selatan dan Faktor-Faktor yang Mempengaruhinya. Jurnal Badan Pendidikan Dan Pelatihan Keuangan 9(2): 216-242.

34. Tambunan, Tulus TH (2016) Pembangunan Ekonomi Inklusif: sudah sejauh mana Indonesia? Jakarta: LP3ES.

35. Green, Anne, Francesca Froy, Erika Kispeter, Paul Sissons (2017) How international cities lead inclusive growth agendas Technical Report January, JRF organization, London.

36. Cahyadi, Ni Made Ayu Krisna, Sasongko, Putu Mahardika Adi Saputra (2018) Inclusive Growth and Leading Sector in Bali Province. Economic Journal of Emerging Markets 10(1): L99-L110.

37. Doumbia, Djeneba (2018) The Quest for Pro-poor and Inclusive Growth: The Role of Governance, Working Paper No.-50, Paris-Jourdan Sciences Economiques, Paris.

38. Sukwika T (2018) Peran Pembangunan Infrastruktur terhadap Ketimpangan Ekonomi Antar wilayah di Indonesia, Jurnal Wilayah dan Lingkungan 6(2): 115-130.

39. Singh M (2012) India's scholar - Prime minister aims for inclusive development. Science, 335 (6071): 907-908.

40. Sanjaya I M (2014) Inklusi Keuangan dan Pertumbuhan Inklusif sebagai Strategi Pengentasan kemiskinan di Indonesia. PhD thesis, Bogor: Institut Pertanian Bogor, Indonesia.

41. Babajide, Abiola A, Folasade B, Adegboye, and Alexander E Omankhanlen (2015) Financial Inclusion and Economic Growth in Nigeria. International Journal of Economics and Financial Issues 5(3): 629-637.

42. Khan M, Serafeim G, Yoon A (2010) Corporate sustainability: first evidence on materiality. The Accounting Review 91(6): 1697-1724.

43. Thorbecke E (2006) The Evolution of the Development Doctrine: 1950-2005, UNU-WIDER Discussion Paper 2006/155. Helsinki: World Institute for Development Economics Research of the United Nations University.

44. Tandon A, Zhuang J (2007) Inclusiveness of Economic Growth in the People's Republic of China: What Do Population Health Outcomes Tell Us?, ERD Policy Briefs. No. 47, Manila: Asian Development Bank, Philippines.

45. Soni P (2007) Global solutions meeting local needs: Climate change policy instruments for diffusion on cleaner technologies in the smallscale industries in India. PhD thesis, VU University Amsterdam, Netherlands.

46. Ali I, Pro-Poor to Inclusive Growth: Asian Prescription", Economics and Research Departement Working Paper Series No. 28. Manila: Asian Development Bank, Philippines.

47. Sholihah, Dyah Hapsari Amalina (2014) Pertumbuhan Inklusif: FaktorFaktor yang Memengaruhi dan Dampaknya Terhadap Kelas Menengah di Indonesia", Sekolah Pasca Sarjana. Bogor: Institut Pertanian Bogor, Indonesia.

48. Sanz M (2015) Micro and small industries, water and developing countries: A challenge for sustainability in Colombia", PhD thesis, Amsterdam: University of Amsterdam, Netherlands.

49. Presetyo H, Sutopo W (2018) Industri 4.0: Telaah Klasifikasi Aspek dan Arah Perkembangan Riset. Jurnal Teknik Industri. 13(1): 17-26.

50. OECD (2018) Growing Unequal? Income Distribution and Poverty in OECD Countries, Paris: Organization for Economic Cooperation and Development.

51. Climate Commission (2013) The critical decade.

52. Maryaningsih N, Hermansyah O, Savitri M (2014) Pengaruh Infrastruktur terhadap Pertumbuhan Ekonomi Indonesia. Buletin Ekonomi Moneter dan Perbankan 17(1): 62-98.

53. Narayan D, Patel R, Schafft K, Rademacher A, Koch-Schulte S (2000) Voices of the Poor: Can Anyone Hear Us? Voices from 46 Countries. The World Bank, Washington DC.

54. Niimi Y (2009) Gender Equality and Inclusive Growth in Developing Asia. ADB Economics Working Paper Series. No. 186. Asian Development Bank, Philippines.

55. UNRISD (2013) Social and Solidarity Economy: A Pathway to Socially Sustainable Development? Geneva: The United Nations Research Institute for Social Development, New York.

56. Tang M (2008) Inclusive Growth and Poverty reduction in the People's Republic of China. Asian Development Review 25(1): 81-99.

57. World Bank (2009) The world bank annual report 2009 - year in review, November. Washington DC, USA.

58. Klasen, Stephan, Measuring and Monitoring Inclusive Growth: Multiple Definitions, Open Questions, and Some Constructive Proposals. ADB Sustainable Development Working Paper Series No.12, Asian Development Bank, Philippines. 
59. Bappenas (2018) Penguatan Pelayanan Kesehatan Dasar di Puskesmas.

60. BPS (2015a) Gini Ratio Provinsi di Indonesia tahun 2014-2015 Jakarta: Badan Pusat Statistik, Indonesia.

61. BPS (2015b) Statistik Indonesia 2015. Jakarta: Badan Pusat Statistik, Indonesia.

62. BPS (2016) Statistik Indonesia 2016. Jakarta: Badan Pusat Statistik, Indonesia.

63. BPS (2017) Statistik Indonesia 2017. Jakarta: Badan Pusat Statistik, Indonesia.

64. BPS (2018a) Statistik Indonesia 2018: Sosial dan Kesejahteraan Rakyat Jakarta: Badan Pusat Statistik, Indonesia.

65. BPS (2018b) Statistik Indonesia 2018. Jakarta: Badan Pusat Statistik Indonesia.

66. BPS (2018c) Angka Partisipasi Sekolah Penduduk Usia 16-18 tahun menurut Provinsi di Indonesia 2014-2018. Jakarta: Badan Pusat Statistik, Indonesia.
67. BPS (2019a) Angkatan Kerja Provinsi di Indonesia 2014-2019. Jakarta: Badan Pusat Statistik, Indonesia.

68. BPS (2019b) PDRB Provinsi di Indonesia atas Dasar Harga Konstan menurut Lapangan Usaha 2014-2019. Jakarta: Badan Pusat Statistik, Indonesia.

69. BPS (2019c) Jumlah Penduduk Miskin menurut Provinsi di Indonesia 2014-2019. Jakarta: Badan Pusat Statistik, Indonesia.

70. BPS (2019d) PDRB Per kapitaatas Dasar Harga Konstan menurut Provinsi di Indonesia 2016-2019. Jakarta: Badan Pusat Statistik, Indonesia.

71. BPS (2019e) Statistik Indonesia 2019. Jakarta: Badan Pusat Statistik, Indonesia.

72. UNCTAD (2010) A More Inclusive Strategy Needed for the MDGs, Policy Brief. 6949, Geneva: United Nations Conference on Trade and Development.

\begin{tabular}{l} 
Your next submission with Juniper Publishers \\
will reach you the below assets \\
- Quality Editorial service \\
- Swift Peer Review \\
- Reprints availability \\
- E-prints Service \\
- Manuscript Podcast for convenient understanding \\
- Global attainment for your research \\
- Manuscript accessibility in different formats \\
( Pdf, E-pub, Full Text, Audio) \\
- Unceasing customer service \\
Track the below URL for one-step submission \\
https://juniperpublishers.com/online-submission.php \\
\hline
\end{tabular}

